Original Research Paper

\title{
Pengembangan Objek Wisata Kampung Wisata Sasak Ende Melalui Penataan Destinasi, Optimalisasi Digital Promotion dan Sumber Daya Manusia di Desa Sengkol
} \author{
Purnama Sari ${ }^{2}$, Anida Firliana Dewi ${ }^{3}$, Yeyen Nilamsari Putri ${ }^{4}$, Zuaem ${ }^{5}$. \\ ${ }^{1}$ Program Studi Pendidikan Biologi, FKIP, Universitas Mataram, \\ ${ }^{2}$ Program Studi Manajemen, Fakultas Ekonomi dan Bisnis, Universitas Mataram, \\ ${ }^{3}$ Program Studi Ilmu Hukum, Fakultas Hukum, Universitas Mataram, \\ ${ }^{4}$ Program Studi Akuntansi, Fakultas Ekonomi dan Bisnis, Universitas Mataram, \\ ${ }^{5}$ Program Studi Teknik Mesin, Fakultas Teknik, Universitas Mataram,
}

Lalu Zulkifli' ${ }^{1}$, Raja Akbar ${ }^{2 *}$, Nuraeni Muntari², Fadhila Karunia Fitri ${ }^{2}$, Putri Ainayah Alfatihah², Nada

https://doi.org/10.29303/jpmpi.v3i2.911

Sitasi: Zulkifli, L., Akbar, R., Muntari, N., Fitri, F. K., Alfatihah, P. A., Sari, N. P., Dewi, A. F., Putri, Y. N \& Zuaem. (2021). Pengembangan Objek Wisata Kampung Wisata Sasak Ende Melalui Penataan Destinasi, Optimalisasi Digital Promotion dan Sumber Daya Manusia di Desa Sengkol. Jurnal Pengabdian Magister Pendidikan IPA 4(4)

\section{Article history}

Received: 1 Oktober 2021

Revised: 30 November 2021

Accepted: 10 Desember 2021

*Corresponding Author: Raja

Akbar, Program Studi

Manajemen, Fakultas Ekonomi dan Bisnis, Universitas

Mataram, Indonesia;

Email: rajarasot@gmail.com
Abstract: Kampung Wisata Sasak Ende yang berlokasi di Desa Sengkol Kecamatan Pujut Kabupaten Lombok Tengah mengalami penurunan jumlah wisatawan baik local maupun mancanegara, hal ini disebabkan antara lain karena adanya gempa bumi yang terjadi pada pertengahan tahun 2018 dan timbulnya pandemi Covid-19 dari awal bulan Maret 2020 hingga sekarang. Oleh karena itu diperlukan usaha pengembangan objek wisata di kampung wisata ende melalui penataan destinasi serta optimalisasi digital promotion. Kegiatan pengabdian ini dilakukan melalui program KKN Tematik Universitas Mataram guna memperbaiki dan menambahkan fasilitas penunjang dan optimalisasi promosi digital terkait Kampung Wisata Sasak Ende tersebut. Metode yang digunakan dalam pengumpulan data adalah dengan cara observasi obyek termasuk wawancara, evaluasi, sosialisasi, dan pelaksanaan kegiatan. Kegiatan utama yang diakukan adalah pembuatan leaflet tentang informasi Kampung Wisata Sasak Ende, digital promotion (melalui media sosial seperti instagram, tiktok, dan youtube), membuat papan spanduk, membuat papan sapta pesona, dan memperbanyak bak sampah, dan pengajaran bahasa inggris untuk anakanak di kampung wisata sasak ende. Dalam pelaksanaan kegiatan pihak Desa dan anggota masyarakat sangat antosias dalam memberi dukungan kerjasama sehingga kegiatan berjalan dengan baik. Hasil kegiatan menunjukkan bahwa Kampung Wisata Sasak Ende menjadi lebih terurus dengan pengoptimalan dan perbaian sarana dan prasarana yang ada untuk mendukung pelayanan bagi pengunjung yang datang, dan diharapkan dengan adaya promosi melalui leaflet dan promosi digital melalui media online dapat meningkatkan kembali jumlah kunjungan ke Kampung Wisata Ende di Desa Sengkol. Kegiatan ini telah dapat menumbuhkan Kembali semangat masyarakat Kampung Wisata Sasak Ende untuk bangkit kembali dan siap untuk menyambut para wisatawan kembali. Selain itu, anak-anak Kampung Wisata Sasak Ende didorong untuk mampu melanjutkan estafet dalam melestarikan budaya mereka sendiri, karena mereka merupakan generasi penerus budaya di Kampung Wisata Sasak Ende itu sendiri. Kampung Wisata Sasak Ende masih memiliki ruang untuk berkembang dan kembali bersaing dalam ruang lingkup destinasi pariwisata di Pulau Lombok.

Keywords: Optimalisasi, Digital Promotion, Kampung Wisata Sasak Ende 


\section{Pendahuluan}

Virus yang muncul di awal tahun 2020, menyebar menjadi pandemi di seluruh belahan dunia. Tidak hanya berdampak bagi kesehatan, namun berdampak pula bagi aspek lainnya terutama pariwisata. Setahun sudah pandemi Covid-19 ini terjadi, mengakibatkan hilang dan berkurangnya pendapatan mayarakat yang dihasilkan dalam aspek pariwisata, sehingga banyak masyarakat menjadi kesulitan ekonomi serta pengangguran terjadi dimana -mana. Dengan adanya program pengabdian kepada masyarakat, diharapkan program tersebut akan meningkatkan data kunjungan pengunjung di berbagai tempat wisata.

Program pengabdian kepada masyarakat ini merupakan salah satu program yang wajib dilaksanakan oleh lembaga pendidikan yaitu pihak kampus, baik oleh dosen maupun mahasiswa dengan tetap berlandaskan pada prinsip - prinsip seperti kompetensi akademik, jiwa kewirausahaan, dan profesinal, sehingga dapat menghasilkan program pengabdian kepada masyarakat yang bermutu, relevan, dan sinergi dalam pemberdayaan masyarakat. Dengan adanya Kuliah Kerja Nyata (KKN) ini, yang merupakan salah satu bentuk pengabdian yang dilakukan mahasiswa kepada masyarakat secara insitusional dan kemitraan sebagai salah satu bentuk tridarma perguruan tinggi.

KKN Tematik di era new normal tahun 2021 periode Juli - Agustus ini merupakan program KKN Tematik yang berfokus pada peningkatan potensi desa yang ada serta perubahan kebiasaan atau pola hidup masyarakat (pelaku wisata) dalam upaya peningkatan pelayanan pariwisata tentunya dengan tetap menerapkan protokol kesehatan yang sesuai dengan aturan. Agar baik pengunjung atau pelaksana aspek pariwisata dapat menekan penyebaran Covid- 19.

Provinsi Nusa Tenggara Barat merupakan salah satu provinsi di Indonesia yang berada di bagian barat kepulauan Nusa Tenggara. Provinsi NTB terdiri dari dua pulau besar yaitu pulau Lombok dan pulau Sumbawa. Pulau Lombok menjadi salah satu pilihan tempat wisata terbaik di Indonesia, baik masyarakat lokal maupun mancanegara karena memiliki berbagai pilihan dan alternatif sehingga tergolong kaya potensi. Pulau yang mendapat julukan sebagai pulau seribu masjid ini memiliki keberagaman budaya. Kawasan pedesaan yang memiliki beberapa karakteristik khusus untuk menjadi tujuan wisata disebut sebagai desa wisata. Kawasan desa wisata harus memiliki berbagai fasilitas penunjang sebagai kawasan tujuan wisata. Di Pulau Lombok, pemerintah kabupaten menyadari pentingnya sarana pendukung, guna meningkatkan jumlah kunjungan wisatawan setiap tahunnya.

Menurut Richardson dan Fluker (2004), destinasi pariwisata didefinisikan sebagai tempat yang dikunjungi dengan waktu yang signifikan selama perjalanan seseorang dibandingkan dengan tempat lain yang dilalui selama perjalanan. Destinasi pariwisata dapat digolongkan atau dikelompokkan berdasarkan ciri-ciri destinasi tersebut diantaranya sebagai berikut ; (1) Destinasi sumber daya alam, seperti iklim, pantai, hutan; (2) Destinasi sumber daya budaya, seperti tempat bersejarah, museum, teater, dan masyarakat lokal; (3) Fasilitas rekreasi, seperti taman hiburan; (4) Event, seperti pesta kesenian; (5) Daya tarik psikologis, seperti petualangan, perjalanan romantis, keterpencilan (Kusdianto, 1996:8). Di Pulau Lombok terdapat 5 wilayah administratif, yakni Kota Mataram, Kabupaten Lombok Barat, Kabupaten Lombok Timur, Kabupaten Lombok Utara dan Kabupaten Lombok Tengah yang memiliki daya tarik dan potensi yang tergolong kaya akan wisata. Dengan ditetapkannya Kawasan Mandalika sebagai Kawasan Ekonomi Khusus (KEK) berdasarkan PP Nomor 52 Tahun 2014, dimana pariwisata menjadi sektor unggulan pariwisata untuk wisata bahari, MICE, maupun wisata budaya. Salah satu potensi wisata budaya yang ada di Lombok Tengah terletak di Desa Sengkol yakni Kampung Wisata Sasak Ende. Kampung Wisata Sasak Ende masih kurang diketahui masyarakat luas, akibatnya masih banyak wisatawan yang tidak mengetahui tentang wisata budaya yang berada di Desa Sengkol tersebut.

Bersadarkan permasalahan di atas, maka kegiatan KKN ini sebagai wadah untuk membantu dalam proses pemberian informasi nilai-nilai kebudayaan dan mengembangkan destinasi wisata sebagai upaya mempertahankan budaya lokal secara turun temurun. 


\section{Metode}

Metode Pelaksanaan yang penulis terapkan dalam program proposal KKN (Kuliah Kerja Nyata) Tematik yang berlokasi di Desa Sengkol, Kecamatan Pujut, Kabupaten Lombok Tengah ini disusun secara sistematis agar sesuai dengn penerapannya. Adapun metode pelaksanaan yang digunakan sebagai berikut :

\section{A. Observasi}

Observasi sasaran menjadi hal yang utama sebelum penulis melakukan pengabdian. Hal ini tentunya akan sangat bermanfaat karena akan mempermudah penulis mengetahui permasalahan yang ada pada lokasi pengabdian, selain itu penulis juga dapat mengetahui potensi yang terdapat pada daerah sasaran pengabdian, sehingga mempermudah penulis untuk mendapatkan solusi untuk permasalahan yang ada.

\section{B. Kontrol Program dan Evaluasi}

Pengontrolan terhadap program dilakukan secara rutin setiap harinya terhadap berjalannya program sesuai dengan tujuan yang ingin dicapai, begitupula dengan evaluasi di setiap hari seusai program dilaksanakan untuk mengetahui kendala dan masalah yang dihadapi saat melaksanakan program. Hasil pelaksanaan akan diukur dengan indikator keberhasilan yang sudah ditentukan, sehingga dapat digunakan sebagai titik tolak bagi program yang akan dilaksanakan berikutnya.

\section{Sosialisasi}

Sosialisasi program kerja dilaksanakan pada awal kegiatan atau sebelum pelaksanaan program yang sudah disusun. Bertujuan untuk menawarkan, memperkenalkan, atau menginformasikan program-program yang akan dilaksanakan selama menjalankan program KKN (Kuliah Kerja Nyata), berbaur, berdiskusi sekaligus mendekatkan diri dengan warga sekitar dengan tetap melaksanakan protokol kesehatan, sembari berdiskusi mengenai kondisi desa dengan aparatur desa, tokoh adat, tokoh masyarakat, dan karang taruna.

\section{Wawancara}

Wawancara dilaksanakan bersama aparatur desa, tokoh adat, tokoh masyarakat, dan karang taruna untuk mengetahui keadaan desa serta informasi yang dapat menunjang eksekusi pelaksanaan revitalisasi program KKN (Kuliah Kerja Nyata) di Desa Sengkol.

\section{Hasil dan Pembahasan}

\section{Profil Desa}

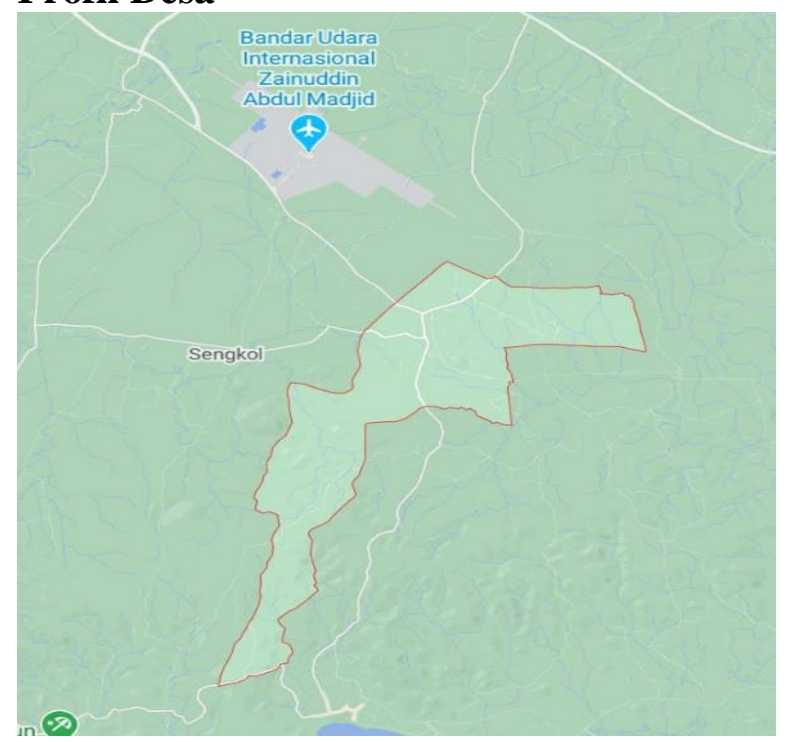

Gambar 1. Peta Desa Sengkol dari Google Maps

Terlihat pada gambar 1 bentang wilayah desa sengkol dilihat dari peta citra dari doogle maps. Desa Sengkol adalah ibu kota Kecamatan Pujut, Kabupaten Lombok Tengah, Provinsi Nusa Tenggara Barat, Indonesia. Pada masa yang lalu, wilayah Sengkol terbentang dari bagian selatan Kota Praya hingga pesisir Pantai Selatan Lombok. Wilayah tersebut meliputi seluruh Kecamatan Pujut, Kecamatan Praya Barat, Kecamatan Praya Barat Daya, dan sebagian wilayah Kecamatan Praya Timur, yaitu di wilayah Desa Kidang dan sekitarnya.

Batas batas wilayah Desa Sengkol di antaranya adalah :

- Sebelah utara : Desa Ketare

- Sebelah selatan : Desa Rembitan

- Sebelah timur : Desa Segala Anyar

- Sebelah barat: Desa Pengembur

Desa Sengkol merupakan salah satu desa yang ada di Kecamatan Pujut, Kabupaten Lombok Tengah. Pujut merupakan sebuah kecamatan di Kabupaten Lombok Tengah, Provinsi Nusa Tenggara Barat, Indonesia. Pusat pemerintahannya berada di Desa Sengkol 
yang berjarak sekitar 15 kilometer tenggara Kota Praya. Kecamatan Pujut lebih dikenal sebagai wilayah Lombok Selatan. Karena berbatasan langsung dengan Samudra Hindia, kecamatan ini juga terkenal memiliki banyak pantai yang indah.

Desa Sengkol terletak 500 meter di atas permukaan laut. Desa Sengkol ini terletak dibagain tengah Kecamatan Pujut. Wilayahnya berupa pantai, dataran rendah dan perbukitan . Desa Sengkol ini memiiki dataran rendah seluas 1.473,00 Ha, perberbukit-bukitan seluas $616,00 \mathrm{Ha}$, lereng gunung seluas $102,79 \mathrm{Ha}$, tepi pantai/pesisir seluas 30,00 Ha dan kawasan rawanya 100,00 Ha. Desa ini tidak memiliki topografi dengan aliran sungai, bantaran sungai, kawasan rawa gambut, daratan tinggi, dll. Luas wilayah Desa Sengkol ini sebesar 2.273,00 Ha. Yaitu terdiri dari luas tanah sawah 470,50 Ha, Luas tanah kering 929,00 Ha tanah kering ini mencangkup luas pemukiman dan perkarangan penduduk ), luas tanah basah 308,50 Ha, luas tanah perkebunan 200,00 Ha, Luas fasilitas umum 45,00 Ha, dan luas tanah hutan 320,00Ha.

Kondisi alamnya di Desa Sengkol ini lebih kering dibandingkan dengan wilayah lainnya di Kecamatan Pujut , Kabupaten Lombok Tengah. Untuk curah hujan Desa Sengkol ini memiliki curah hujan sebesar $110,00 \mathrm{~mm}$, dengan jumlah bulan hujan 7 bulan, dan suhu rata rata harian sebesar 32 derajat celcius. Sebagai wilayah dengan kondisi alam yang kering, satu sistem bertani yang dikembangkan di wilayah ini adalah sistem "Gogo Rancah" atau disingkat GoRa. Dengan sistem ini, petani harus mengolah sawahnya pada waktu musim kemarau dengan tujuan, pada waktu musim hujan, tanah yang sudah diolah tersebut sudah siap tanam dan musim hujan yang pendek akan memberi cukup air dibandingkan jika sawah diolah pada waktu musim hujan. Memang sistem tersebut menuntut petani untuk bekerja lebih keras. Tapi, tampaknya sistem pertanian tersebut cukup berhasil dan hingga saat ini hanya sistem tersebut yang ada.
Desa Sengkol membawahi 19 dusun yaitu; Dusun Sengkol I, Dusun Sengkol II, Dusun Sengkol III, Dusun Sengkol IV, Dusun Sowang, Dusun Semundal, Dusun Kekale, Dusun Pampang, Dusun Piyang, Dusun Gerupuk, Dusun Penambong, Dusun Junge, Dusun Lemuh, Dusun Jomang, Dusun Tonjer, Dusun Loang Landak, Dusun Ebangah, Dusun Sekencang, dan Dusun Tajuk. Jumlah penduduk Sengkol yang sudah didata sebanyak 9674 jiwa. Jumlah laki-laki 4927 orang, jumlah perempuan 4747 orang, Jumlah kepala keluarga 3486 KK dan Kepadatan Penduduk 1256,4 per $\mathrm{km}^{2}$. Jumlah tersebut terjadi peningkatan jumlah jiwa yang disebabkan oleh adanya kelahiran bayi, perpindahan penduduk, serta warga Desa Sengkol yang berada di luar daerah dan luar negeri. Kepercayaan / agama yang dianut oleh penduduk Desa Sengkol terdiri dari berbagai agama dan etnis, yaitu agama Islam dan etnis Sasak sebagai mayoritas penduduk.

Desa Sengkol merupakan salah satu desa tertua di Kabupaten Lombok Tengah, Provinsi Nusa Tenggara Barat (NTB). Selain tertua, desa ini kaya akan budaya dan adat istiadat yang terus dilestarikan masyarakat. Desa Sengkol memiliki banyak pantai dengan panorama alam yang indah, diantaranya yaitu Pantai Tanjung Ann, Bukit Merese, dan Pantai Gerupuk. Di Pantai Tanjung Aan dan Bukit Merese ini setiap tahun (biasanya pada bulan Februari) terdapat tradisi tahunan yang juga menjadi annual tourist event, yaitu "Bau Nyale" (menangkap nyale). Tidak hanya itu, Desa Sengkol juga memiliki wisata lain seperti rumah adat yang salah satunya berada di Desa Sengkol, yaitu Kampung Sasak Ende dan wisata religi yaitu Masjid Kuno Gunung Pujut. Oleh karena keberagaman wisata yang terdapat di Desa Sengkol ini yang menjadikan Desa Sengkol merupakan salah satu desa yang wilayahnya masuk sebagai kawasan pengembangan pariwisata nasional Kawasan Ekonomi Khusus (KEK) Mandalika. Tepatnya di Dusun Gerupuk Lauk, Dusun Ebangah, dan Dusun Gerupuk Daye. Kawasan yang akan 
menjadi lokasi MotoGP 2021 berlangsung. Untuk mempersiapkan kemajuan pariwisata di desanya, tahun ini Pemdes Sengkol terus menggenjot program pendukung melalui program pemberdayaan. Diantaranya melalui pelatihan pembuatan pakan ikan, pelatihan atau pendampingan kelompok usaha ekonomi produktif, dan sejumlah program lainnya. Bahkan untuk mendukung itu, Pemdes Sengkol juga memperkuat usaha dari BUMDes di Desa Sengkol. Perkembangan pembangunan infrastruktur penunjang MotoGP 2021 juga terlihat. Seperti pembangunan rumah sakit berstandar internasional.

\section{B. Pelaksanaan Program}

Selama proses pelaksanaannya, program pengabdian KKN (Kuliah Kerja Nyata) Era New Normal di Desa Sengkol, Kecamatan Pujut, Kabupaten Lombok Tengah dengan mengambil tema "Pariwisata dan Lingkungan" melalui program kegiatan yaitu, program proyek di desa wisata sudah berjalan dengan lancar. Hal ini dapat dilihat dari meningkatnya kesadaran dan minat masyarakat sekitar dalam menjaga kelestarian lingkungannya setelah diadakannya sosialisasi terkait pentingnya sadar wisata dan ilmu mengenai pemanfaatan lingkungan sekitar dalam meningkatkan perekonomian daerah wisata, terciptanya lingkungan yang asri sesuai dengan sapta pesona (aman, tertib, bersih, sejuk, indah, ramah dan kenangan) di kawasan objek wisata Kampung Wisata Sasak Ende (Sulartiningrum, dkk., 2018). Penulis melakukan digital promotion dengan cara pembuatan konten-konten promosi dan mengadakan lomba fotografi untuk kegiatan promosi di kawasan objek wisata Kampung Wisata Sasak Ende dan Pantai Tanjung Aan melalui berbagai media sosial seperti TikTok, YouTube, dan Instagram. Disamping itu, penulis juga melakukan penambahan fasilitas penunjang operasional, baik itu di kawasan objek wisata Kampung Wisata Sasak Ende maupun objek wisata Pantai Tanjung Aan. Selain berfokus pada pengembangan objek wisata Kampung Wisata Sasak Ende dan Pantai
Tanjung Aan, penulis juga melaksanakan program dalam meningkatkan SDM pada kelembagaan pariwisata di Kampung Wisata Sasak Ende serta untuk meningkatkan kesadaran terhadap pemuda pemudi mengenai pentingnya melestarikan budaya lokal. Selain itu penulis juga turut berpartisipasi dalam program lingkungan bersih yang diadakan oleh BSF (Black Soldier Flies) Sengkol (berlokasi di Dusun Kekale, Desa Sengkol) yang berkerjasama dengan PT. Bumi Sejahtera. Berikut deskripsi singkat serta dokumentasi pendukung terkait program KKN (Kuliah Kerja Nyata) Tematik Era New Normal Universitas Mataram yang berlokasi di Desa Sengkol, Kecamatan Pujut, Kabupaten Lombok Tengah.

\section{Sosialisasi Program Kerja KKN}

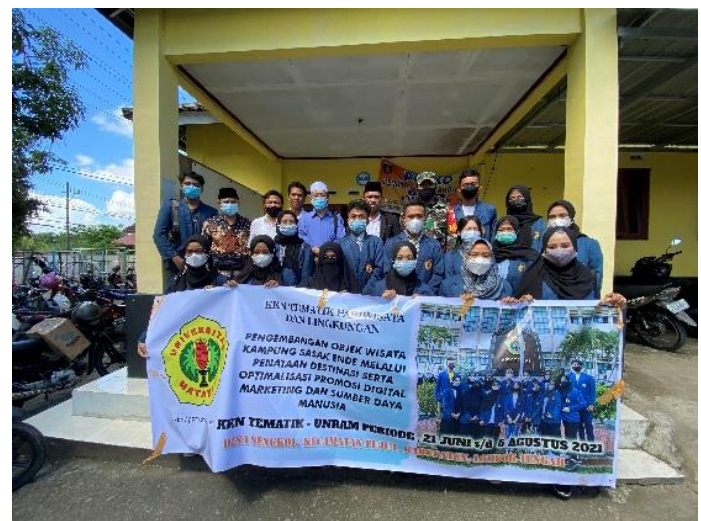

Gambar 2. Sosialisasi Program Kerja sekaligus Pelepasan KKN Tematik Unram Desa Sengkol 2021 di Aula Kantor Desa Sengkol

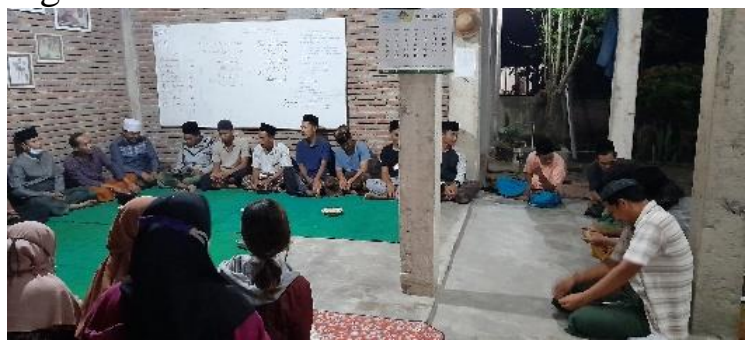

Gambar 3. Sosialisasi Program Kerja bersama Karang Taruna Dusun Kekale, Kepala Dusun Kekale, dan Lalu Edy Gunawan di Dusun Kekale - Sengkol 


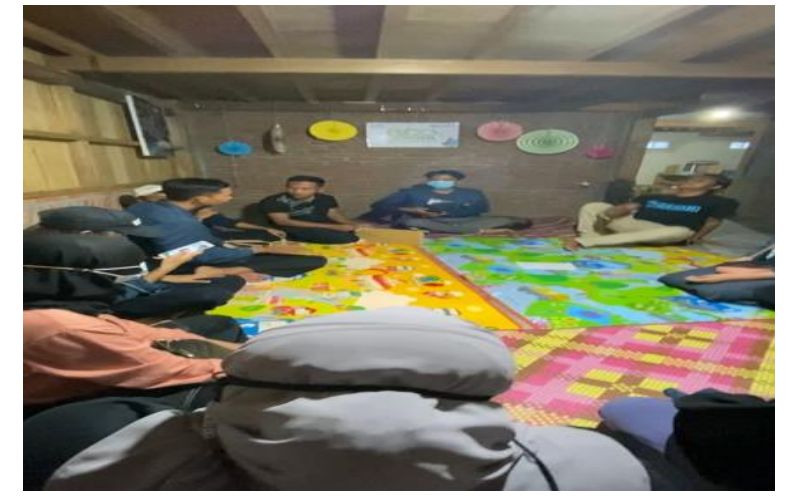

Gambar 4. Sosialisasi Program Kerja bersama Ibu Eliyan di Ecoschool Nusantara)

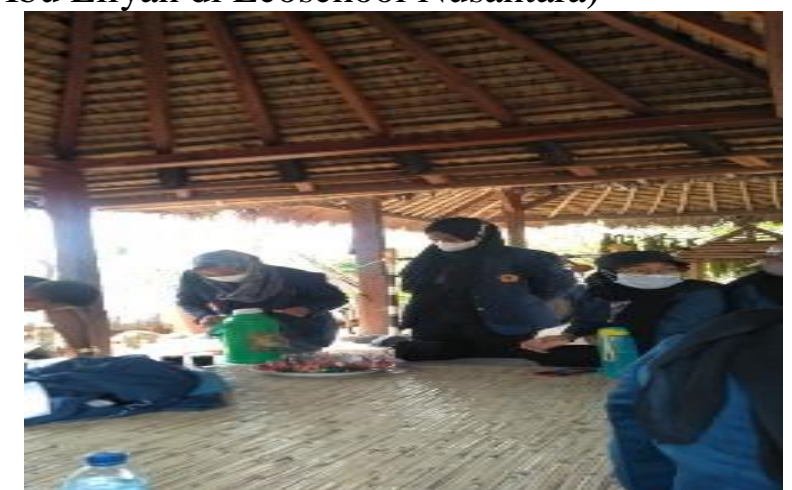

Gambar 5. Sosialisasi Program Kerja dengan Kak Tantowi dan Kak Yoga selaku Ketua dan Sekretaris POKDARWIS di Kampung Wisata Sasak Ende.

Sosialisasi ini diadakan di Aula Kantor Desa Sengkol tampak pada gambar 2 dan gambar 3, Sosialisasi program kerja yang dilakukan di posko yang terlihat pada gambar 4 yang berlokasi di Dusun Kekale - Sengkol, Ecoschool, serta di Kampung Wisata Sasak Ende dengan mengundang Kepala Dusun Kekale dan Kepala Desa Sengkol serta staf kantor desa. Sosialisasi Program kerja kepada ketua dan sekretaris POKDARWIS terlihat pada gambar 5. Adanya pelaksanaan program ini menjadikan masyarakat mengetahui tentang program yang akan dilaksanakan oleh mahasiswa KKN, menerima, dan memberikan masukan kritik serta saran dari masyarakat.

\section{Promosi Wisata}

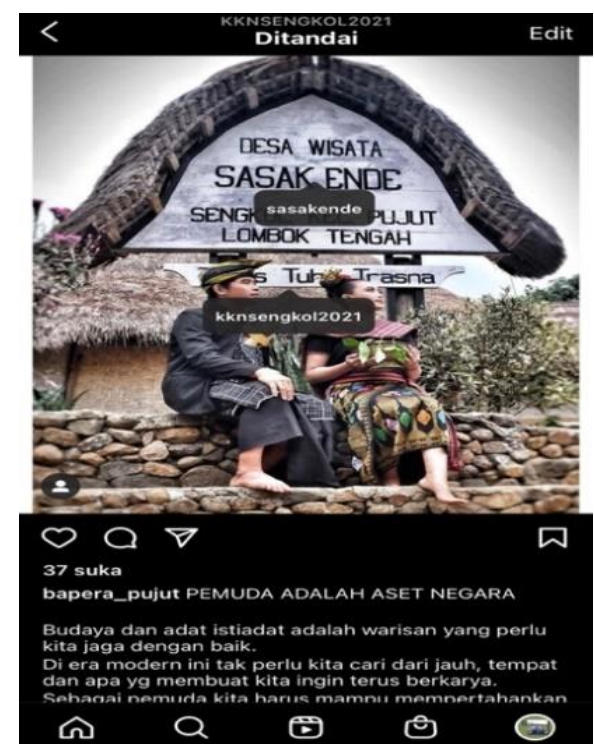

Gambar 6 Promosi Wisata Kampung Sasak Ende-Sengkol dengan Diadakannya Lomba Foto Instagram

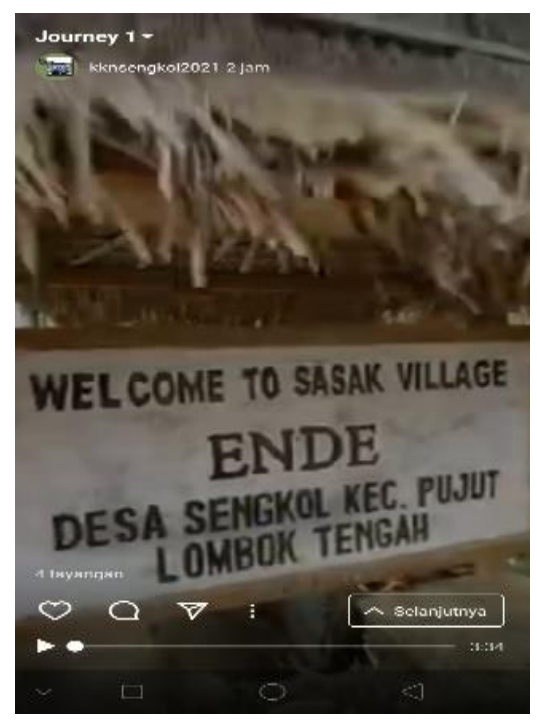

Gambar 7 Promosi Wisata Kampung Sasak Ende - Sengkol di Instagram 


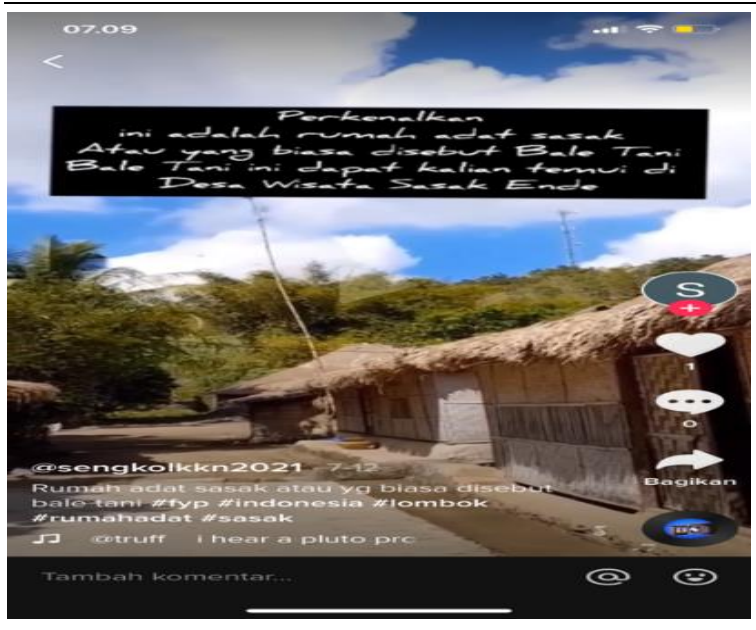

Gambar 8 Promosi Wisata Kampung Sasak Ende di TikTok

Promosi dilakukan melalui media sosial, pada Gambar 6 melalui Instagram, gambar 7 melalui TikTok, dan Gambar 8 melalui YouTube, ini merupakan program wajib melalui media sosial. Setelah diadakannya promosi wisata ini, masyarakat luas mengetahui adanya tempat wisata yang tidak kalah menarik dengan tempat wisata yang terkenal di luar daerah.

\section{Perbaikan dan Pengadaan Fasilitas Penunjang Operasional}

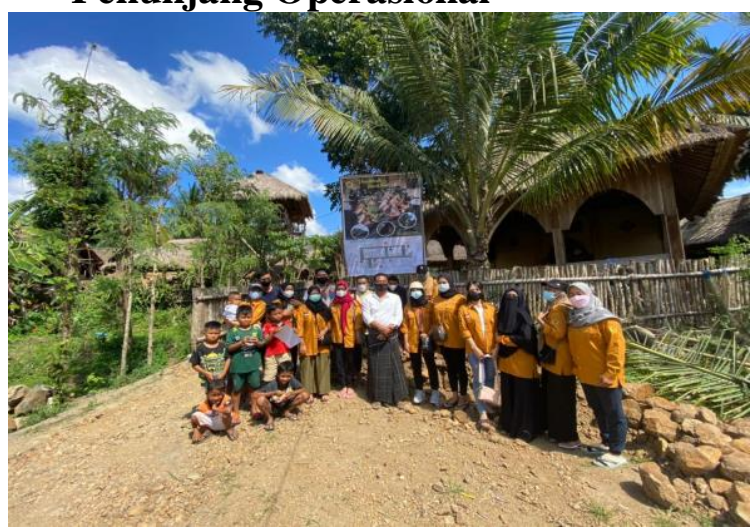

Gambar 9 Pengadaan Papan Spanduk Pemberitahuan Mengenai Tata Lokasi atau Denah di Kampung Wisata Sasak Ende

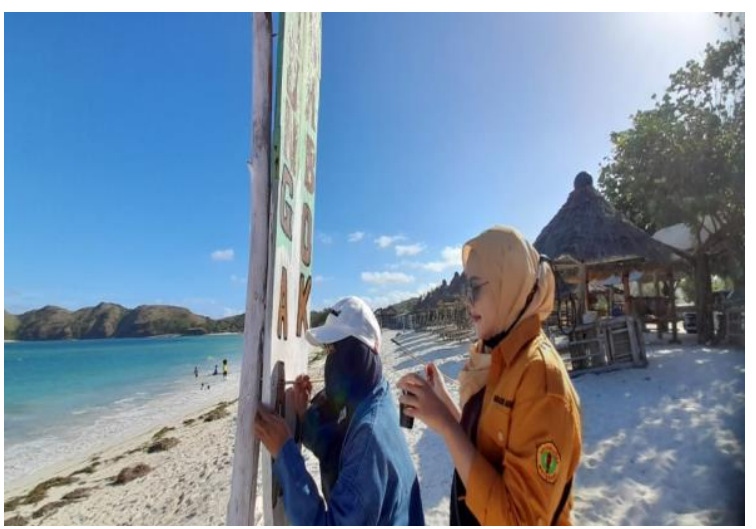

Gambar 10 Merenovasi Sarana Wisata Ayunan dengan Mengecat Ayunan di Pantai Tanjung Aan.

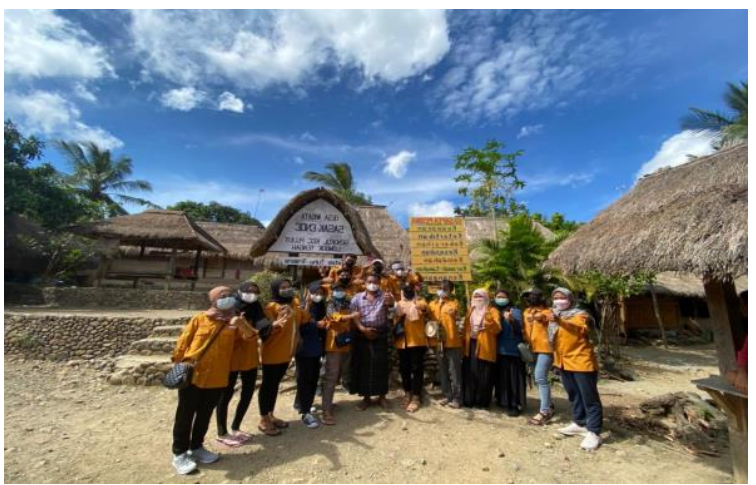

Gambar 11 Pengadaan Papan Sapta Pesona di Kampung Wisata Sasak Ende

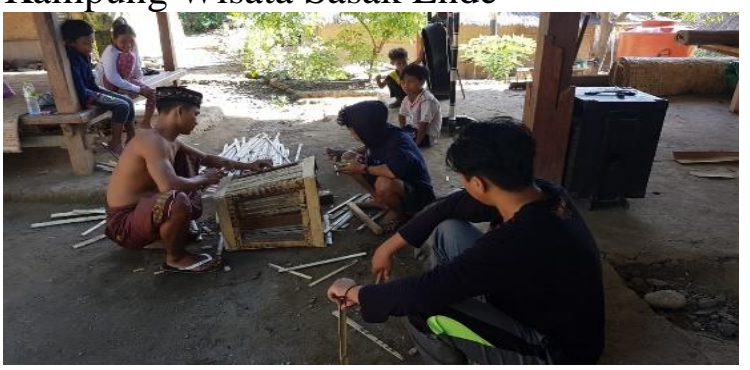

Gambar 12 Pengadaan Bak Sampah yang Terbuat dari Bambu dan Kayu di Kampung Wisata Sasak Ende

Terlihat pada gambar 10 dilakukan perbaikan fasilitas di pantai Tanjung Aan dan pada gambar 9, 11 dan 12 merupakan pengadaan fasilitas penunjang operasional wisata di kawasan Kampung Wisata Sasak Ende. Perbaikan dan pengadaan fasilitas di Kampung Wisata Sasak Ende dan Pantai Tanjung Aan bertujuan agar dapat tampil dengan wajah baru dalam rangka 
mempersiapkan diri dalam era new normal. Program ini merupakan program wajib.

\section{Jum'at Bersih}

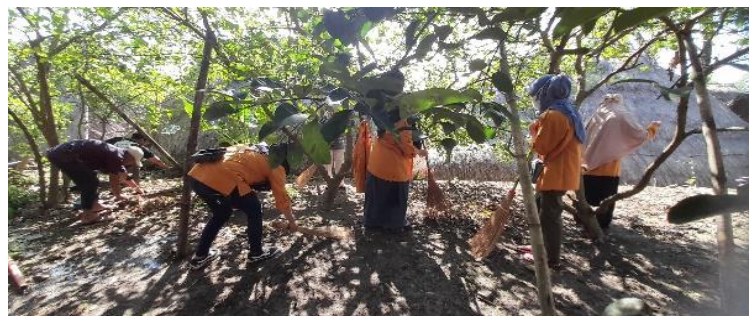

Gambar 13 Melakukan Kegiatan Jum'at Bersih di Kampung Wisata Ende

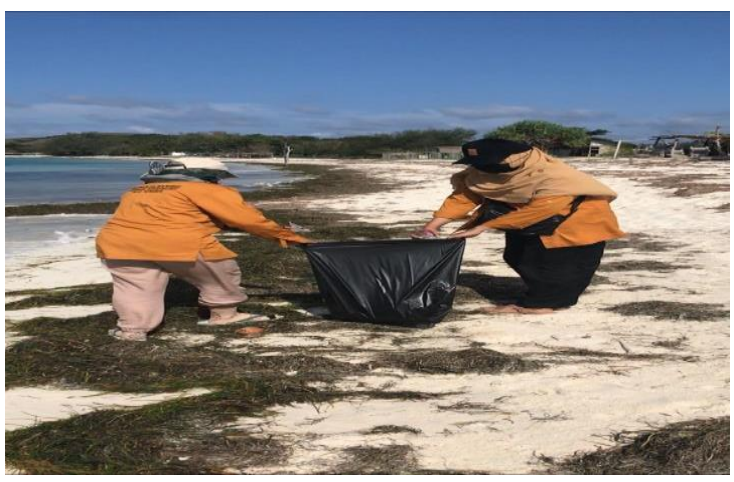

Gambar 14 Melakukan Kegiatan Jumat Bersih dengan Memungut Sampah Plastik di sekitaran Pantai Tanjung Aan

Program yang terlihat pada gambar 13 dan 14 ini merupakan program wajib dan ditujukan untuk tetap menjaga kebersihan lingkungan di sekitar kawasan Kampung Wisata Sasak Ende dan Pantai Tanjung Aan, maupun ditempat umum di Desa Sengkol.

\section{Sabtu Mengajar}

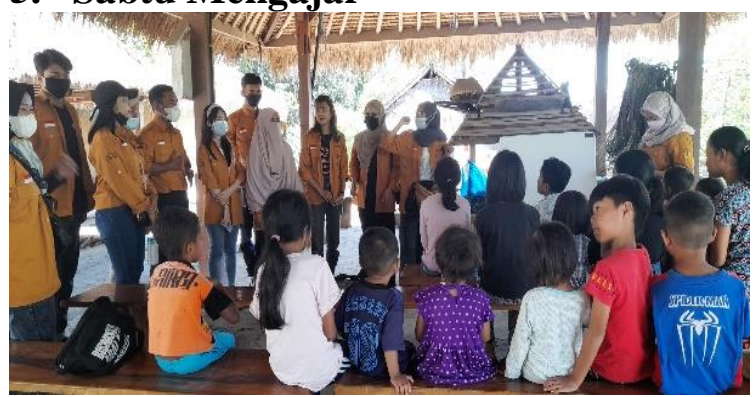

Gambar 15 Melakukan Kegiatan Mengajar Bahasa Inggris di Kampung Wisata Sasak Ende.

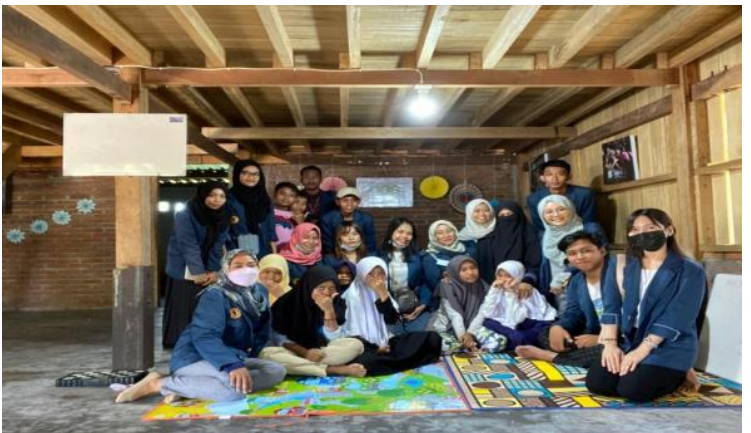

Gambar 16 Melakukan Kegiatan Mengajar Bahasa Inggris di Ecoschool Nusantara Sengkol.

Program yang terlihat pada gambar 15 dan 16 ini merupakan program wajib dan ditujukan untuk meningkatkan kemampuan berbahasa Inggris terhadap anak-anak di kawasan Kampug Wisata Sasak Ende maupun Echoschool Nusantara di Desa Sengkol.

\section{Peningkatan Sumber Daya Manusia}

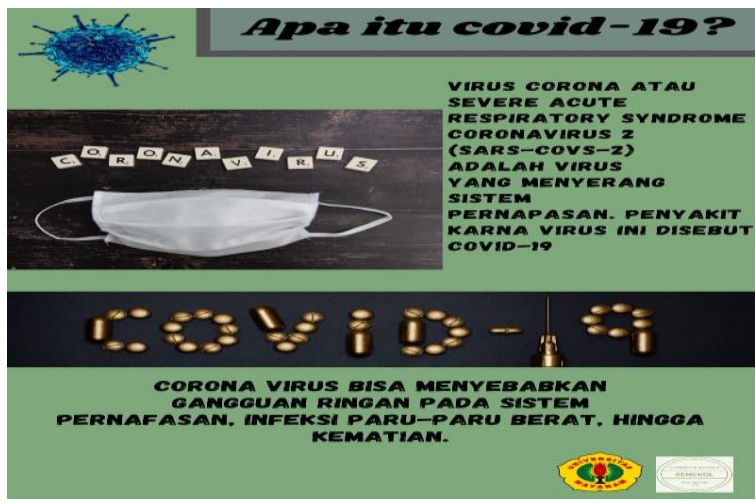

Gambar 17 Kegiatan Sosialisasi Online melalui Penyebaran Pamflet ke Instagram sebagai Program Lanjutan.

Program lanjutan pada gambar 17 bertujuan untuk mensosialisasi Covid 19 guna mengedukasi masyarakat sekitar 


\section{Pengelolaan Lingkungan Bersih}

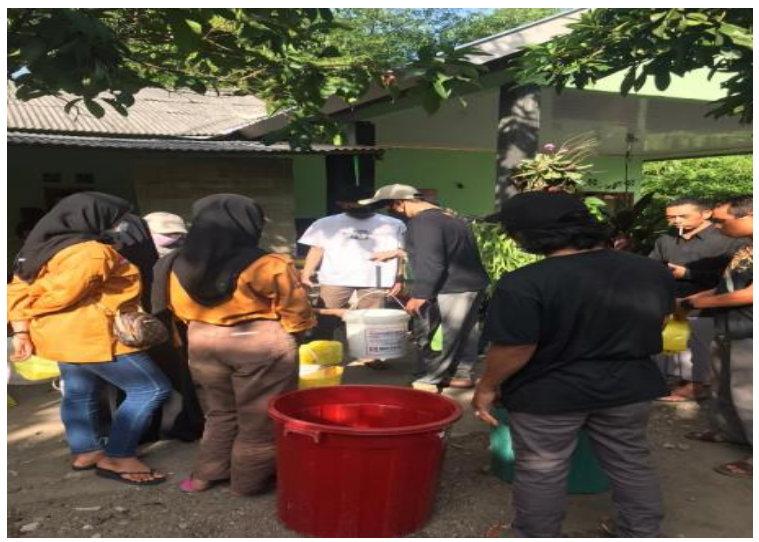

Gambar 18 Melakukan Penimbangan Sampah, Pengangkutan Sampah, dan Pengolahan Sampah di Fasilitas BSF Sengkol yang Terletak di Dusun Kekale.

Program lingkungan bersih pada gambar 18 merupakan program tambahan yang diadakan oleh BSF (Black Soldier Flies) Sengkol (berlokasi di Dusun Kekale, Desa Sengkol) yang berkerjasama dengan PT. Bumi Sejahtera. Program ini merupakan program pengolahan sampah organik basah melalui metode Black Soldier Flies.

\section{Kesimpulan}

Berdasarkan hasil dan pengamatan yang dilakukan selama kegiatan Kuliah Kerja Nyata ini berakhir dengan judul "Pengembangan Objek Wisata Kampung Sasak Ende Melalui Penataan Destinasi Melalui Optimalisasi Promosi Digital Promotion dan Sumber Daya Manusia". Dapat disimpulkan bahwa penerapan digital promotion sebagai media dalam mempromosikan Kampung Wisata Sasak Ende dapat berjalan dengan baik dan memenuhi indikator-indikator keberhasilan yang telah ditetapkan sebelumnya. Penulis telah mampu meningkatkan kesadaraan serta menjadi inisiator sekaligus pelakasana dalam pengembangan dan pembangunan di daerah kawasan Kampung Wisata Sasak Ende dan masyarakat Desa Sengkol

\section{Ucapan Terimakasih}

Penulis menyampaikan terima kasih kepada Rektor Universitas Mataram dan Ketua LPPM, serta Kepala Desa Sengkol dan pihak2 yang telah membantu terlaksananya semua program KKN ini.

\section{Daftar Pustaka}

Berita Bali, Sengkol, Desa Tertua di Lombok Jadi Ikon Wisata MotoGP, https://www.suara.com/partner/content/ beritabali/2020/01/31/105218/sengkoldesa-tertua-di-pulau-lombok-jadi-ikonwisata-motogp/. Diakses pada 3 Agustus 2021 pukul 09.08 WITA

Budasi, I Gede. 2012. IbM Kelompok Sadar Wisata. Laporan Akhir. Fakultas Bahasa dan Seni: Universitas Pendidikan Ganesha Singaraja.

Hasibuan, Malayu. 2003. Manajemen Sumber Daya Manusia. Jakarta: Bumi Aksara.

Inskeep, E. 2010. Tourism Planning An Integrated and sustainable Development Aproach. Oxford :OUP.

Karini, Zulia., Marcos, Hendra., Idah, Munsa Yusida. 2018. Kelompok Sadar Wisata (POKDARWIS) Desa Wisata LIMBASARI Kecamatan Bobotsari Kabupaten Purbalingga. Jurnal Pengabdian Kepada Masyarakat. 2(2) : 73-82.

Pitana, I Gde. 2008. Sosiologi Pariwisata. Yogyakarta: Andi Offset.

Peraturan Pemerintah Nomor 52 Tahun 2014 tentang Kawasan Ekonomi Khusus Mandalika

Pusat Penelitian dan Pengembangan Kebijakan Kepariwisataan Badan PEngembangan Sumber Daya Pariwisata dan Ekonomi Kreatif Kementrian Pariwisata dan Ekonomi Kreatif. 2012. Pengembangan Wisata Bahari di Indonesia. Jakarta: Pusat Penelitian dan Pengembangan Kebijakan Kepariwisataan.

Richardson, John and Fluker, Martin. 2004. Understanding and Managing Tourism, Australia: Pearson Education 
Sulartiningrum, Sri., Nofiyanti, Fifi., Fitriana,

Rina. 2018. Pelatihan Peningkatan Kualitas SDM Bidang Pariwisata di Desa Wisata.

Jurnal SOLMA. 7(2) :176-181. 